\title{
Critical Methods in International Relations: the politics of techniques, devices and acts ${ }^{1}$
}

\section{Claudia Aradau \& Jef Huysmans}

\author{
Claudia Aradau \\ Department of War Studies \\ King's College London \\ Claudia.Aradau@kcl.ac.uk \\ Jef Huysmans \\ Centre for Citizenship, Identities and Governance \\ Department of Politics and International Studies \\ The Open University (UK) \\ Jef.Huysmans@open.ac.uk
}

\begin{abstract}
Methods have increasingly been placed at the heart of theoretical and empirical research in IR and social sciences more generally. This article explores the role of methods in International Relations and argues that methods can be part of a critical project if reconceptualised away from neutral techniques of organising empirical material and research design. It proposes a two-pronged reconceptualisation of critical methods as devices which enact worlds and acts which disrupt particular worlds. Developing this conceptualisation allows us to foreground questions of knowledge and politics as stakes of method and methodology rather than exclusively of ontology, epistemology or theory. It also allows us to move away from the dominance of scientificity (and its weaker versions of systematicity and rigour) to understand methods as less pure, less formal, messier and more experimental, carrying substantive political visions.
\end{abstract}

Keywords: Methodology, critical international relations, scientificity, STS, intertextuality, ethnography

\section{Introduction}

What does it mean to approach the discipline of International Relations through methods and methodology? What effects does methodology have on the critical and political questions asked by the discipline, how does it shape the modes of inquiry undertaken by students of IR and what relation does it bear with critical approaches in

\footnotetext{
${ }^{1}$ The article is an outcome of work we did within the International Collaboratory on Critical Methods in Security Studies (ICCM), an ESRC funded International Networking and Training Opportunities project (ESRC RES-810-21-0072). We would like to thank the members of the ICCM, the participants in the ICCM workshops, the journal editors and two anonymous reviewers for helpful comments on earlier versions of this article.
} 
the discipline? Methods have increasingly been placed at the heart of theoretical and empirical research in IR and social sciences more generally. Publishers fund numerous textbooks on methods, postgraduate students are required to take methodology courses (rather than say, theory courses) and funders require long statements about method. On the one hand, methods, both qualitative and quantitative, are seen to drive research, rigour, systematicity, objectivity and credibility in social sciences (e.g. Klotz and Lynch 2007; Sprinz and Wolinsky-Nahmias 2004; Yanow and Schwartz-Shea 2006). On the other, methods have been criticised for their disciplining or 'hygienising' function, to use John Law's terminology (2004). The substantive political disagreements and the differences in visions of the world that are at the heart of debates are seen to be neutralised by discussions on techniques of gathering and processing data, the search for shared methods of establishing universal truths, and an investment in the idea of the unity of social science. It is perhaps therefore not surprising that critical debates in IR have shifted either towards ontology or towards epistemology. Despite other differences, constructivist, poststructuralist, feminist and critical realist scholars would largely agree on this move towards ontology and/or epistemology contra the disciplining force of method (e.g.Harding 1989; Lundborg and Vaughan-Williams 2011; Tickner 1997; Walker 1993; Wendt 1999; Wight 2006). In this view, methodology can only be rescued when separated from the tyranny of method and reframed as an overarching epistemological and meta-theoretical reflection. Methodology is thus subsumed within ontology, epistemology and theoretical arranging of concepts structuring the discussions, while method becomes at best a reflection on the tools for organising empirical material and practical research design.

The main criticism formulated against method and traditional methodologies concerns their instrumentalisation as a 'guarantee' for the scientific and orderly/ordered research that the discipline aspires to. However, a series of critical IR scholars have turned a more attentive eye to methodology and have integrated reflections on methodology within critical projects. For instance, Jennifer Milliken's (1999) article on discourse analysis has become a reference text for constructivist and poststructuralist approaches. More recently, Lene Hansen (2006) has placed methodology firmly at the heart of debates in critical security studies. Intervening in the debates about the role of science in IR, Patrick Jackson (2011) foregrounds methodology as the main site of reflection. In the wake of a growing interest in ethnography, the Review of International Studies recently published a series of articles on autoethnography as a critical intervention in IR (Bleiker and Brigg 2010). Debates on ethnographic research as a methodology for critical IR have also recently proliferated (Gusterson 2008; Rancatore 2010; Vrasti 2008; Wedeen 2010). Similarly, constructivists and interpretive approaches have increasingly reclaimed methodology away from positivism and ideas of methods as 'free-floating tools unmoored in conceptual space' (also Friedrichs and Kratochwil 2009; Yanow 2006b: 8). Well before this renewed focus on criticality and methodology, Hayward Alker (1996) had foregrounded methodological questions in his proposal for a humanist approach to IR. Method and methodology have also been at the heart of feminist debates - from Christine Sylvester's formulation of 'empathetic cooperation' as a feminist method for IR (1994b), Cynthia Enloe's Bananas, Beaches and Bases (1989) to the recent edited book by Ackerly, Stern and True on Feminist Methodologies in International Relations (2006).

Taking our cue from some of these reflections on method and the status of methodology, we argue that method and methodological reflections can be a key site 
of revisiting critique and politics in International Relations research. This requires two closely interrelated moves. First, methods need to be understood as performative rather than representational (Law 2004; Law, Ruppert, and Savage 2011; Law and Urry 2004). They are not simply techniques of extracting information from reality and aligning it with - or against - bodies of knowledge. Methods are instead within worlds and partake in their shaping. As performative, methods are practices through which 'truthful' worlds are enacted, both in the sense of being acted upon and coming into being. This move implies a reversal of the usual order of discussion that subsumes method and methodology to debates driven by the formulation of a problem-question, an ontology, an epistemology and a conceptual toolbox. The concept of method we propose does not treat methods as an outcome of particular ontology and epistemology so that a particular method can only be used in relation to certain philosophical positions. ${ }^{2}$ Methods are instead performative practices experimentally connecting and assembling fragments of ontology, epistemology, theories, techniques and data through which substantive effects are obtained. ${ }^{3}$

The second move we make is to conceptualise methods as political rather than value neutral. They interfere through enacting substantive, and/or rupturing positions on social and political questions. The disciplinary politics of methods is not new for critical scholars both in IR and social sciences more broadly. For Dvora Yanow, methods are political as they entail contestations among scholars and bring about a 'power element in the accreditation of knowledge' (Yanow and Schwartz-Shea 2006: 28). Therefore, methods are not instruments for creating common ground but for power struggles, competing enactments of worlds and/or creating disruptive positions in the worlds of international politics.

In similar terms to Yanow, John Law has argued that methods partake of at least two 'goods': truth and politics (2004: 148-9). ${ }^{4}$ Rather than subsuming method to the single question of science and what counts as scientific and non-scientific, Law shifts the understanding of methods and what methods do to the entwined questions of truth and politics. While taking our cue from this recasting of method beyond the 'science question', we argue that the politics of method can be understood slightly differently if we conceptualise methods as 'devices' and 'acts'. Understood as devices, methods are seen to enact social and political worlds. Understood as acts, methods can become disruptive of social and political worlds. This dual reconceptualisation also allows us to derive an understanding of critical methods.

We therefore ask: what happens to critical research in International Relations if we insert questions of critical methods and not just critical theory, of substantive

\footnotetext{
${ }^{2}$ Compare Colin Wight's argument that 'methodology (...) is a normative exercise, since it stipulates that given certain ontological posits, certain methods should be employed rather than others.' (2006: 259)

${ }^{3}$ See also e.g.: Alker (1996: 64-103). We do not use systematically as sharp a distinction between methodology and method as some other authors do. Yet, at places we do work loosely with the oftenused distinction between method and methodology. Method refers then to the techniques of extracting information from an object and methodology to systematic reflections on principles guiding investigation and its modes of aligning ontological, epistemological, conception, design and data elements. Our conception of method as experimental connection of ontology, epistemology, technique, concepts, and data requires us however to avoid using a sharp distinction between the two. The distinction is often used to introduce a hierarchy in which methods become the mere expression of ontological and epistemological approaches rather than a substantive practice where ontological and epistemological choices are constructed. Such a hierarchising of the abstract, the concrete and the tools connecting them is what we seek to move away from in our conception of method.

${ }^{4}$ Law's use of 'truth' here is consonant with Michel Foucault's 'regimes of knowledge' rather than the universal truths of science.
} 
political vision and not just methodological plurality at the heart of our inquiries? Starting from this question, we explore what critical projects of IR are possible when acknowledging method as a focal point of enquiry; a point of view that is often seen to either precisely neutralise political stakes invested in knowledge or to only derive those from pre-existing theoretical and ontological investments. ${ }^{5}$ To this purpose, the article proceeds in three steps. First, we revisit some of the texts and debates that have placed questions of methodology and method on the IR agenda in critical ways. Given some impasses and limitations in this literature, we then move on to our first reconceptualisation of methods as 'devices' and unpack the knowledge and political stakes invested in this concept of method. In a third step, we turn to methods as 'acts' to draw out different modalities of engaging knowledge and politics critically. We conclude with a series of remarks on the implications of this twofold reconceptualisation for critical IR research.

\section{A critical methodological 'turn'? Challenging methods as techniques}

The discipline of International Relations has quickly embraced the language of 'turns'. For instance, the 'linguistic' or 'rhetorical turn' (Neumann 2002), the 'constructivist turn' (Checkel 1998), the 'aesthetic turn' (Bleiker 2001), the 'ethical turn' (Frost 1998), the 'ethnographic turn' (Vrasti 2008) or the 'material turn' (Aradau 2010) have functioned both as political projects and forms of academic capital (and capitalisation). The list of turns in the discipline could be seriously expanded if one were to search the titles and abstracts of articles and books published during the past 20 years or so. However, the metaphor of 'turns' is also problematic, inasmuch as it assumes a clear break between a 'before' and 'after' as well as relatively coherent forms of inquiry (a turn to something else). In a sense, the language of 'turns' is unhelpful for understanding what goes on in the discipline. Yet, for our purposes, inserting critical methodology in the discourse of 'turns' can work to signify a particular presence-absence of critical method in IR, particularly as different 'methodological turns' have already been formulated in IR. ${ }^{6}$

Methods and methodology are present - even excessively so - in the practices of funding research and drawing boundaries between research 'worth' doing and research which has not been thought out carefully, properly or sufficiently. ${ }^{7}$ The problem with this excessive and dominant presence of methods has been aptly captured by Law:

If 'research methods' are allowed to claim methodological hegemony or (even worse) monopoly, and I think that there are locations where they try to do this, then when we are put into relation with such methods we are being placed,

\footnotetext{
${ }^{5}$ There are some significant exceptions to this point of view. The so-called second big debate in IR between behaviouralist and traditionalist approaches expressed profound political and knowledge stakes to a considerable extent in methodological terms. The work of Christine Sylvester, Sandra Harding, Cynthia Enloe, Michael C. Williams or Hayward Alker, among others, has shown the profound intertwining of methodological choices with political issues.

${ }^{6}$ Hansen (2006) has argued, for instance, for a 'poststructuralist methodological turn'.

${ }^{7}$ In the UK, the Economic and Social Research Council (ESRC) has set up, for instance, a national research methods centre and funded research methods programmes. According to the ESRC, the programme 'aimed to develop quantitative and qualitative methods within the context of substantive research and to promote the effective dissemination of good practice through a range of related training activities' (ESRC n.d.). The motto for the ESRC National Centre for Research Methods is 'Learn a new method'.
} 
however rebelliously, in a set of constraining normative blinkers. We are being told how we must see and what we must do (Law 2004: 13). ${ }^{8}$

Contrary to the proliferation of methods as a disciplining and constraining tool, critical academic practice has taken up a strategy of distancing from the limits and constraints of methodological requirements. ${ }^{9}$ This has led to a double move: on the one hand, the privileging of ontology and on the other of epistemology. Ole Waever's (1996) analysis of the inter-paradigm debates captures this move away from methodology towards ontology and epistemology in the third and fourth debate. In contrast to the realism/liberalism and behaviourism/traditionalism debates, the third debate involved questions about the ontological and epistemological assumptions used in different paradigms (realism, liberalism, Marxism). The fourth debate (rationalism/reflectivism) has often been represented as one over epistemology, the role of science and modes of knowledge-making. For Waever, the fourth debate is strongly philosophical; it is about 'basic assumptions regarding objectivity, subjectivity (the author, signature and the work), object/subject distinctions, the use of dichotomies, the rule of Western metaphysics over seemingly diverse ways of thought, and about referential versus relational conceptions of language, and much, much more' (Waever 1996: 156-7). In the separation that he draws about how questions of politics, philosophy, epistemology and methodology surface in one or other of the four debates, methodology is related to the second debate (behaviourism/traditionalism) and only secondarily to the third debate. Debates are analysed in terms of the primacy of one of these elements. Method and methodology have the tendency to be pushed to the background and associated with earlier debates. Moreover, the taxonomy also enacts an implicit separation between methodology and politics. Particularly in post-positivist approaches, 'methods' appear increasingly tainted by the allegation of 'positivism', 'naturalism' and 'empiricism'. Therefore, a methodological inquiry can be seen as inherently suspect for a critical approach. Methods appear suspect, as if they were somehow both less critical (when not uncritical) and less political.

Ken Booth's (2007) redefinition of constructivism as method is perhaps exemplary in these implicit or explicit accusatory practices. If ontology and epistemology are to be privileged - and politics is ensuing out of the ontological assumptions about the world - methods are 'less than political'. In Theory of World Security, Booth opposes 'theory' to 'method' and deems constructivism to be of the latter category:

First, contrary to many assumptions, social constructivism is not a theory of international relations. It tells us nothing about politics among nations in the way that realism, for example, does, with its categorical realities of states, power, anarchy, and strategy. Constructivism is a method, or meta-theory, about the way human society (including international relations) works. (Booth 2007: 152 emphasis in original).

By being just a 'method', constructivism is doubly relegated to the non- or a-political - it is unable to be political inasmuch as it doesn't oppose a 'theory' to dominant theories and it is non-political inasmuch as it cannot lead to contestation. According to

\footnotetext{
${ }^{8}$ See also Anne Norton (2004) and William Connolly (2004) on similar arguments about the role of method in political science.

${ }^{9}$ See, however, Alker (1996) and Sylvester (1994a, 1994b).
} 
Booth, constructivism as just a method 'is no more use politically than the political assumptions that underlie it' (Booth 2007: 468). ${ }^{10}$ Ironically, Booth accuses constructivism of exactly what constructivists have tried to hold at a distance - being just a method of research.

Given the assumption of methods as ultimately disciplining, many critical IR theorists have privileged ontology and epistemology (see e.g.Walker 1993) as political at the expense of methodology ${ }^{11}$. Yet, one could also read Booth's claims against the grain and reformulate the accusation addressed to constructivism into a question about how methods can be understood as practices of problematising and intervening in the world. This also implies that methods can garner critical and political weight in ways that had so far only been reserved for theory, ontology and epistemology.

More recently, several interventions in IR have attempted to claim method and methodology (respectively) away from accusatory practices and as an integral element of critical projects. The reasons for the foregrounding of methodology are as varied as they are numerous. For Vincent Pouliot (2007), the stakes for methodological specification are in the communication between different constructivist approaches which otherwise have incompatible ontological and epistemological assumptions. For Friederichs and Kratochwil (2009: 710), the issue is to produce useful knowledge on the basis of a pragmatic methodology that understands scientific inquiry as 'taking place in communities of practice'. Jackson (2011) locates the stakes of methodological debates in the scientificity of IR as a discipline. For Ackerly, Stern and True (2006: $\mathrm{x}$ ), what counts is the 'methodological rigour that could make a difference to the world we live in'. Lene Hansen's book on security as practice (Hansen 2006: 4) also reclaims rigour by arguing that a non-causal epistemology is not contradictory to "theoretically rigorous frameworks, empirical analyses of "real world relevance", or systematic assessments of data and methodology'. These analyses place methodology within critical theoretical projects by enacting a subtle secondary distinction between method and methodology.

Jackson's reflections on the conduct of inquiry in IR and Hansen's methodological reflections on foreign policy debates are in this sense particularly interesting for our purposes. Like others before him, Jackson sharply distinguishes between 'method' and 'methodology': 'methods are techniques for gathering and analysing bits of data, whereas methodology is "a concern with the logical structure and procedure of scientific enquiry" (Sartori 1970, 1,033)' (Jackson 2011). Method continues to serve an accusatory function as it works as 'mere technique', largely unaware of (or indifferent to) the philosophy of science which Jackson advocates in methodological reflection. His remarks on the instrumental role of the philosophy of science in this distinction are worth quoting at length:

Philosophy of science is not going to teach anyone how to run a multivariate regression testing hypotheses about democracy and economic growth, or how to craft an ethnographic account of the activities of the Ministry of Foreign Affairs, but it can help us think through the decision to utilize those methods, and make sure that we are using research methods in ways that complement one another or generally hang together [...] Indeed, absent at least a broad agreement on strategic questions about the character and status of knowledge, it is unlikely

\footnotetext{
${ }^{10}$ Method as an accusatory language is widely used in critical IR: e.g. Milliken (1999).

${ }^{11}$ Hence the call in IR for 'decolonizing methodology' (Smith 2006).
} 
that the tactical debates about how best to achieve those strategic goals could even take place (Jackson 2011: 25).

For Jackson, thinking IR through methodology is a matter of discussing the scientificity of knowledge. His politics is that of knowledge production in the discipline under the claims of systematicity, ontological compatibility and coherence. Jackson's main argument is that there are different models of scientific knowledge that are incompatible with one another but each with their own rigorous criteria for evaluating the scientific quality of knowledge. ${ }^{12}$ Although Jackson proposes methodology to become a focal point of debate in IR where ontology, epistemology, research design and data gathering can meet, he refocuses the debate immediately onto the ontological and epistemological by privileging methodology so thoroughly over method. Method is an instrumental matter of bridging the gap between theoretical representations of the world and the world itself, and methodology is firmly set on the terrain of meta-theory.

This distinction between method and methodology allows for critical inquiry to be located in the methodological debates (philosophy of science). For instance, Colin Wight's redescription of methodology is illuminating for the high stakes that the distinction carries: 'methodology refers to the critical examination and evaluation of research procedures and techniques (methods) as to their ability to provide us with more or less reliable knowledge for the research problem at hand' (Wight 2006: 271 emphasis ours). Criticality is immediately connected with the interest in methodology at the expense of method.

While Jackson, Pouliot, and Wight attempt to pluralise methodologies in IR research, the overarching commitment to scientificity is not without problems. Firstly, as noted by feminist scholars, there are 'unseen androcentric or masculine biases in the way that knowledge has traditionally been constructed in all the disciplines' (Tickner 2006). Moreover, the 'rational exemplar of proper science' (Sylvester 1994a: 316) effects a whole series of separations and exclusions, relegating women to the realm of the non-scientific. However, feminist methodological research does not entirely jettison ideas of scientificity. Rather, in recent engagements with methodology, it recasts the criteria of rigour, systematicity and objectivity from a feminist perspective. In our reading, rigour and systematicity are the most often endorsed characteristics of methodological writings in feminist and poststructuralist work (see for instance Ackerly, Stern, and True 2006; Alker 1996; Hansen 2006). In a fascinating piece on rigour and objectivity, Yanow (2006a) reclaims these philosophical concepts from their restricted meaning in methodology textbooks in order to show that interpretive work can be both rigorous and scientific. A shift takes place that allows a loosening of the grip of methods as techniques, without breaking free nonetheless.

Developing post-positivist methodologies and countering the idea that different approaches can ultimately come together around shared methodologies is

\footnotetext{
12 This argument is similar to Wight's discussion of methodology and method in relation to agencystructure debates in IR (Wight 2006: 257-271) and the one formulated by Pouliot from within constructivist debates. Pouliot draws on Ian Hacking's notion of 'styles of reasoning' to capture different modes of scientificity - each style of reasoning has a particular object and creates its own modes of truth and the verification of the true and false. However, although Hacking has identified six such styles of reasoning: axiomatic, experimental, analogical, taxonomical, statistical and historical (Hacking 2004), the exact number of scientific styles of reasoning has been debated, thus raising questions about the limits of scientific plurality.
} 
especially critical in institutional contexts where methodological arguments are used to create a hegemonic vision of scientific international studies. Yet, important as this argument is in certain academic contexts, for us the critical moves of these contributions lie elsewhere. More specifically, this literature foregrounds debates on methodology as a central point of entry into studying international politics, thereby turning attention to what usually remains at best secondary. Moreover, it indicates that methodology is a question of thinking together epistemology, ontology, theory and empirical developments rather than simply doing epistemology or mediating the gap between theory and empirics. Finally, Jackson in particular inserts an interest in unpacking conceptions of worlds that are embedded in methodological thought, thereby challenging Booth's understanding that methodology does not deliver substantive visions of world politics and thus neutralises the possibility for critical knowledge. As Sylvester and Tickner remind us, methods are not only critical stakes in the discipline and social science knowledge more widely but they are also political stakes. To use Mary Hawkesworth's (2006: 48) particularly apt formulation, methods do not 'only construe the political world differently, but also act subtly to promote specific modes of political life'.

These moves set the parameters for a critical methodological turn that indeed can carry the meta-theoretical debates of the 1980s and 1990s - the fourth debate - into a new terrain and create a significant opening for a much closer relation between claims of criticality, politicality and method. Yet, in some sense this literature also limits the promise of the project. By making 'scientificity' or a version of rigour or systematicity the stake or interest that defines methodological debates, it privileges epistemological debates in the philosophy of science and combines them with an ontological argument about logically incompatible worldviews that are invested in epistemological differences. At least equally limiting is the stark separation between method and methodology in most of the literature, thereby relegating methods to the dustbin of history (i.e. to that what is not really making history and is not part of the world). Somehow formulating a methodological turn in which methods are at best a secondary or derivative concern doesn't feel like it has pursued critique all the way.

We would like to argue that a critical methodological turn needs to make the extra step to tackle these two limitations. First, rather than marginalising methods, we seek to reinforce critical projects by returning methods to the heart of methodology and thereby avoiding the 'philosophical fetishization of distinctions' between method and methodology (Harding 1987: 25). Of course, this will require a particular understanding of 'method' that makes it a ground for the experimental connecting and assembling of ontology, epistemology, methodology and worlds. Second, and simultaneously, we argue that it is important to turn the interest in a critical methodological 'turn' from scientific modalities of knowledge only to political stakes too. A critical methodological turn is invested in a reconceptualisation of methods which makes apparent both knowledge and political stakes. It is in this sense that we can speak of critical methods. To this purpose, we reconceptualise methods as 'devices' and 'acts'. The next section turns to the first aspect of this reconceptualisation.

\section{Methods as devices}


While methods have largely functioned as techniques linking empirical worlds with worlds of theoretical abstraction in as undistorted ways as possible, methods understood as devices are performative, they enact social and political worlds. ${ }^{13}$ In this sense, methods 'have effects; they make differences; they enact realities; and they can help to bring into being what they also discover' (Law and Urry 2004: 393). They are devices that interfere in the worlds in which they are deployed. Methods are not techniques of representation that simply extract information from externally given worlds while leaving the worlds they represent untouched. The device of extraction enacts worlds in the sense that it is an active force that is part of a process of continuous production and reproduction of relations, an endless process of bringing worlds into being. For example, some forms of geographical mapping are a practice of creating the world as a global whole and geopolitical entity. The colour-coding, line drawing, and naming are crucial elements of the mapping that brings the geopolitical world into being. ${ }^{14}$ Visualisation methods, for example, enact particular worlds both in relation to the 'war on terror' and climate change. The scientific visualisation and modelling of climate change has 'actively secured the production of political responses' (Yusoff 2009: 1010). Data mining methods deployed to govern terrorism also enact futures as unexpected, catastrophic, worst case scenarios (Amoore 2009; Aradau and Van Munster 2011). Similarly statistical analyses of the relation between migration and crime sustain the criminalisation of migration, irrespective of the conclusion of the analysis, by interrogating migration through the lens of crime. Mike Savage's fascinating inquiry into the effects of social science methods in Britain in the 1950s and 1960s brings out the role these had in the emergence of a 'modern, rational nation which was amenable to intervention and 'management', and which depended on defining a homogeneous nation, with clear geographical boundaries, made up of specific groups'(Savage 2010).

Treating methods as performative devices is in some sense quite obvious, especially when illustrating it by how specific methods, like mapping, visualisation, data mining or statistics function in social and political worlds. Yet, it also has a surprising edge to it, as it opens up the possibility to understand methods not as an application of meta-theoretical and theoretical visions or neutral mediation between these visions and reality but as part of the repertoire of devices where knowledge exists and is created in action rather than representation. The concept of 'inscription device' is used in STS (Science and Technology Studies) to bring into focus how knowledge production does not take place exclusively in discussions about the meaning and significance of inscriptions produced in books, the statistical tables, scans, etc. but also in the workings of the inscription devices themselves, or in other words, in the material production of the inscriptions. According to Law, an inscription device is a system (often including, though not reducible to, a machine) for producing inscriptions, or traces, out of materials that take other forms (Law 2004: 20). The map is not exactly the same as the water, air, soil or states that are being mapped. Neither do statistical numbers reproduce the thick social contexts in which crime and migration take place.

Inscription devices can be graphs, dictionaries, diagrams, machines or narrative forms that, in Latour's words, 'draw things together' (Latour 1990). The critical methodological turn we are interested in is not just a turn towards

\footnotetext{
${ }^{13}$ We have preferred the terminology of 'devices' as it has informed the rethinking of methods in science and technology studies and has allowed to devise a different vocabulary for conceptualising methods. A similar move could also be made by reinterpreting 'techniques' in a Foucauldian way.

${ }^{14}$ See for example John Agnew's (1998) analysis of the modern geopolitical imagination.
} 
methodology - the logos of method - but a foregrounding of methods as material devices that enact worlds. In a recent book that approaches methods in a material and performative way, devices are seen to act as a 'hinge[s] between concepts and practice, epistemology and ontology, the virtual and the actual' (Lury and Wakeford 2012: 9). These can be devices used by doctors, scientists, market analysts, diplomats, IR scholars, counter-insurgency experts, and so on. For example, network analysis is used by security professionals as well as by critical security analysts and IR scholars (Hafner-Burton, Kahler, and Montgomery 2009; Ressler 2006); statistical clustering is used in Bourdieuean field research as well as in intelligence work (Robson and Sanders 2009). As devices, methods enact social and political worlds in multiple ways - the world of terrorism is different when accounted for by mapping global inequalities rather than by mapping terrorist networks.

We use the concept of enactment instead of 'construction' or 'constitution' to keep the fragility of the entities thus made in focus. 'Construction' and 'constitution' tend to emphasise stabilisation. The notion of 'enactment' has been introduced in methodological literature 'to allow objects and subjects to change over time, enable their identity to be fragile, and allow them to differ from site to site' (Ruppert 2011: 223). This understanding of methods makes it impossible to treat methods as simply a matter of bringing theory in contact with reality, contemplation with factuality; representation with that what they represent. Rather, they make and remake worlds, identities, and things in a fragile, continuously changing way.

The consequences for how we understand method are significant. In most of the literature the concepts of method and methodology mobilise a demand for rigour, systematicity, scientificity, or generalisability. 'Method' names the practice in which the messy production of traces is moved to the background so that the inscriptions can unproblematically stand in for the reality they are referring to. In that sense, methods are a tool not only of the production of representations but also of rendering these representations hygienic - taking away the dirt, the material production and selectivity, that sticks to the traces so that the inscriptions into graphs, papers, narratives, diagrams, etc. can be taken as standing in for reality (Law 2004). This is the idea of methods as techniques which leads many IR theorists to separate methods from methodology and to consider methods as mere application of a pre-given set of tools where nothing really exciting happens. Yet, inscription devices render these distinctions messier by including interpretations of how methods enact realities by excluding some and forgetting others. (Law 2004) Excluded realities differ from forgotten ones in the sense that they remain recognisable within the methodological practice despite not being turned into data. For example, using statistical analysis to identify social patterns often excludes the worlds of individual experiences and the lives that are lived but deviate significantly from the pattern. The lives that are lived differently, for example a group of the poor doing and consuming high culture but too small to be statistically significant, remain outside of the traces that are produced but can remain present as that was is kept outside. Some other realities are not counted in the sense of simply not being considered; they exist as forgotten worlds, worlds the method erases from the enactment of patterns of cultural consumption and level of income. In that sense, methods are substantive in their effects.

Taking methods as devices does not imply that ontology, epistemology and theory are secondary. Rather our argument is that methods are devices that experimentally connect and assemble ontology, epistemology, theory, and worlds by putting them into knowledge generating action. In other words, to foreground methods is not a move to reverse the priority of methodology over method but rather 
to emphasise the effects methods have. The central point is to see methods as devices of connecting and assembling, as well as the effects this obtains in the social and political worlds in which methods operate. The connecting is an experimental, messy and possibly failing process of assembling.

To illustrate how methods as devices allow us to understand the enactment work that methods do through connecting and assembling, we look at how Hansen has developed intertextuality as a method for foreign policy and security analysis, drawing on poststructuralist insights. For Hansen,

Understanding foreign policy texts as intertextually linked across a variety of media and genres calls for empirical analysis of how these links are made as well as for thoroughly theorizing the way in which texts build authority and their capacity to speak about a particular issues (Hansen 2006: 55).

Intertextuality implies a particular understanding of what texts are and how they generate meaning. In line with the linguistic turn, the texts perform or constitute foreign policy and identity through reference to other texts. Foreign policy is performed in links between texts across genres. These texts gain authority and obtain capacity to speak policy partly by being interwoven with other texts. Intertextuality is the methodological core in Hansen's work, which moves smoothly from metatheoretical reflections about post-structuralism and theoretical reflections about international politics over translating these reflections into models of analysis followed by research design and concluding with an analysis of debates on the Bosnian war. Although these different steps are presented as moving from the philosophically more substantive and general to practicalities of research, they are connected and work together.

In our reading the important choices are not just made in the discussion of post-structuralism and theorisation of identity in foreign policy. Intertextuality can be seen to function as an inscription device that draws together a series of things/documents and orders them in particular ways. To illustrate this, let's look at the instructions on selecting texts. The first is that 'a majority of texts should be taken from the time under study' but historical texts that relate to them should also be included (Hansen 2006: 82). A second instruction states that key texts are those which are 'frequently quoted and function as nodes within the intertextual debate' (Hansen 2006: 82). At first sight this reads simply like a piece of sound advice. Why would one take a piece of text that is not really referred to or why would one collect a set of texts randomly from an archive? Yet, something more substantive is implicated in these selection criteria. By emphasising representativeness of a particular time and assigning significance on grounds of relative quantity of being referenced, intertextuality selects and processes texts in a quite specific way. The selection criteria have an impact on how meaning is inscribed on the archive and the texts it contains. Intertextuality is used as a device fixing identities. In addition, it introduces extra-textual references to the archive to discriminate between the authoritative capacities of texts. Although the analysis is extended to unusual genres of texts like travel writing, Hansen also instructs that one should definitely include governmental texts as the starting point since one is studying foreign policy.

In a project interested in political identity construction this may sound quite obvious. Yet, the care that is taken in instructing quite precisely how to action intertextuality arises partly, we suspect, from the possibility to action it differently. In particular, Hansen's intertextual inscription device differs from the actioning of 
intertextuality by Kristeva (1980, 1986). Kristeva focuses on demonstrating the inherent instability or contingency of meaning; intertextuality is a deconstructive rather than identification device. For her, the world is in the first instance inside the text and not connected to institutional sources and political contestation. The intertextual references are mobilised to show how meaning within a text is necessarily unstable and by implication how fixing meaning requires a strategy of constructing and reproducing a particular set of interpretations, be it one that never fully succeeds given that meaning is inherently instable. Rather than fixing meaning, intertextuality creates uncertainty about what the text is actually saying; it critiques the naturalising power of texts, the taken for granted nature of meaning. The representativeness of a text on grounds of the number of quotations and the institutional source of the text is not crucial. Any text can be used to analyse the non-foundational nature of meaning. The two intertextualities are not unrelated - Hansen also draws on Kristeva, and more generally on poststructuralist philosophy, and has an interest in de-naturalising meaning. Yet, there are two different devices at stake that connect similar metatheories, theories, and worlds differently in the actioning of discourse analysis.

Understanding methods as connecting and assembling of ontology, epistemology, concept development, techniques of data gathering and worlds - rather than simply being the expression of ontological and epistemological choices - is an important step. At the same time, something else is implied. If methods are an active practice of bringing these various elements in relation rather than being simply the expression of an alignment that is cascaded down from ontology and epistemology over theory and concept building to methods, then methods must be experimental in their work of connecting and assembling. Philosophical coherence between the various elements is less important than tentative and explorative assembling of ontological and epistemological perspectives as well as data and concept fragments in relation to a research question or set of issues that drive the development of knowledge, such as the securitisation of migration, the transformation of geopolitics, the rise of risk governance, the prevention of human trafficking, regulation of free movement and so on. The concept of device that we propose is therefore probing and messy rather than logically and procedurally strict. This performative conception of method makes the interferences methods make central to their evaluation rather than the logical systematicity of their alignments (see also the illustration taken from feminist work in next section). It changes the principles guiding scientific research from rigour and systematicity to experimentation and bricolage. In some sense this understanding of methodology is self-evident because this is how scientific practice often works despite the systematicity and logicality in which they are presented. (Latour 1999) Yet, making this understanding of method explicit can free research practice from constraints that the demand of systematic alignment poses and encourage more intense and explicit experimental combinations and inventions. (Rabinow 2003)

This understanding of research activity differs from what Wight and Jackson, for example, propose. For us method is performative, fragmented, and incomplete but also disruptive. (The disruptive aspect will be developed in the next section). Both Wight's prioritising of ontology and Jackson's classification of methodology in philosophical ideal types propose a vision of closed, coherent 'systems of knowledge', which function as a normative benchmark against which one can measure the nature and quality of research in light of their ontological and epistemological position. For us, methods are always also a practice of experimenting with scripted procedures and of transgressing boundaries. Its messiness is a positive 
rather than discrediting quality. Is our method then one of 'anything goes'? In some sense it is, but in a sociological sense it is not. Research activities take place in communities, dialogue, struggle, etc. They are the places were seriousness is sanctioned but also reconfigured. Importantly, these communities, conversations, struggles are not only academic. They include political actors imposing criteria, researchers using webtools, citizen scientists, etc.

This understanding of methods implies that Jackson's argument for letting a plurality of methodologies co-exist misses something important. Arguing for pluralism is an important move in the academic context, of which we are supportive, but it does not bring into focus the politicality of the choices within the pluralist canvas. The field of a thousand blooming methodological flowers is also a field of contestation and struggle, and not simply about what is the best way to do science, but also about what subjectivities and worlds are being brought forward in the enactment of methods. Once one accepts that methods enact worlds, the question of methods necessarily is a question of conflicting, competing, diverse 'conceptions' of worlds and subjectivities - a question of both knowledge and politics. As Law, Ruppert and Savage (2011: 12) have put it, this means that '[w]e're also trading in politics, in questions about the kinds of social worlds and subjectivities we want to help make more real - to realise - in and through our methods'.

Method as device allows us to turn a critical eye to the deployment of methods, be those positivist or post-positivist, quantitative or qualitative. Firstly, we can make visible the visions of the world that methods enact. For instance, John Law's work on survey as a method used in Eurobarometer reports makes clear that the survey, among others, 'enacts the EU as a neoliberal political site; performs Europe as an isomorphic population of individuals in a homogenous bounded, conceptual space; reproduces statistics and survey research as reliable tools for describing and so enacting social reality, and naturalizes a philosophical romantic version of the collective' (Law 2009: 249). Secondly, the messiness of methods means that we can destabilise connections and instituted methodological conventions Finally, we can also create different connections within these processes of assembling. Countermapping is a well-known example of experimenting with method in ways that enact worlds differently. ${ }^{15}$

At this point the question of critical knowledge becomes inevitably connected to a methodological turn. Criticality is about the limits of knowledge but also about the substantive worlds that are enacted through the production of knowledge. In the next section, we seek to capture the political possibilities it gives rise to by interpreting methods as acts rather than enacting devices, as we have done so far.

\section{Methods as acts}

The second of the two interrelated moves we make for the reconceptualisation of methods interprets methods as acts. As the previous section has shown, methods enact particular worlds and they work as knowledge in these worlds. Yet, methods as devices enact worlds in fragile ways that only become temporarily stabilised. At times devices fail, at other times they succeed in enacting particular worlds, in formulating

\footnotetext{
${ }^{15}$ See the counter-mapping project led by students at Queen Mary's university in London, which renders visible the role of the university within wider circuits of power and knowledge: http://www.culturalstudiesassociation.org/lateral/issue1/countermapping.html.
} 
truthful knowledge and intervening politically by shaping the world, be it in minute ways. Methods as devices carry particular modes of criticality - alternative knowledge is possible by making explicit the implicit definition of a world - and politicality - enactments imply struggles over given social arrangements and interferences in these arrangements.

By enacting particular worlds and simultaneously making others less visible or invisible, methods as devices partake of and act upon regimes of knowledge and politics. We have already mentioned the role of social network analysis and its increased popularity both with security experts and sociologists. Another debate has recently focused on the role of ethnographic methods and the regimentation of anthropological knowledge for the purposes of counterinsurgency operations (see e.g. Gusterson 2007). Ethnographic methods have been mobilised in the production of and struggles over particular arrangements based on privileged access to local conditions and populations. At the same time, these claims to knowledge raise political questions about the relations between anthropologists and security experts for instance, between researchers and subjects, as well as about the political effects of the ethnographic methods one adopts. In response to the politics of ethnographic methods in counterinsurgency operation in the 'war on terror', anthropologists have tightened the ethics of research and have passed their methods through renewed critical scrutiny. ${ }^{16}$ However, if the call for critical scrutiny of ethnographic practices and 'engaged anthropology' has focused largely on the ethics of research rather than ethnographic method, our conceptualisation of methods places the criticality and politicality firmly at the centre of debates about methods. It is thus not only a question of ethical or unethical deployments of ethnographic method, but also a question of the politics of ethnography as method.

If methods enact particular worlds, their experimental connecting and assembling can also create ruptures in these worlds. To render these disruptive effects that methods can have, we refer to methods as 'acts'. To stay with ethnographic methods, which have gained increased attention in IR, the centrality of politics was made visible in a debate opened by Loic Wacquant's (2002) accusations against urban ethnography in the US that it played into the neoliberal ideology of 'welfare reform'. In a review of three ethnographic books which documented the lives of the urban poor, Wacquant argues that their authors adopted categories of popular perception as analytical categories, romanticised and moralised the poor and thereby played the ideological game of neoliberalism with its emphasis on individual responsibility, morality of labour and 'values'. Ethnographic methods appeared enmeshed with neoliberal policing of the poor and the state's 'carceral-assistential complex' (Wacquant 2002). Against this 'naïve' ethnography, Wacquant proposes a Bourdieuinspired sociological method which is attentive to historical forces, embodied agencies and dispositions as well as class and race relations. Yet, proposing a structural method of analysis is not really a 'safeguard' against incorporation by governmental rationalities and practices, as structural methods can also be seen as connected with the rise of the Fordist welfare state in the 1960s and 1970s (see Clough 2010). Wacquant's engagement with method can nonetheless be read as an attempt to reformulate method as disruptive and political.

The understanding of methods as devices draws the analysis to the question of how methods enact worlds, both as being part of social and political practice and as

\footnotetext{
${ }^{16}$ See for instance Jeffrey Sluka's (2010) reply to an article published in Military Review asking for a closer relationship between anthropologists and the military. A series of other articles on this topic have been published in Anthropology Today: Fluehr-Lobban (2008), Gonzalez (2007), Albro (2010).
} 
creating worlds, such as populations (Hacking 2007) and communities of insecurity (Huysmans 2006). Our conceptualisation of methods as acts introduces another aspect to the criticality and politicality of methods. Methods as acts can be understood in a stronger sense as disrupting worlds. In reconceptualising methods not just as devices but also acts, we draw inspiration from the distinction that Engin Isin has drawn between acts and 'habitus, practice, conduct, discipline and routine as ordered and ordering qualities of how humans conduct themselves' (Isin 2008: 27). In everyday language, acts refer to what is done as well as the process or practice of doing. An act is performative just like a device. This is the sense in which 'speech acts' have been used. At the same time, an act allows us to place more emphasis on disruptive outcomes than performativeness and enactment imply. Unlike the emphasis on order and ordering practices in much of social science, acts emphasise rupture and disruption. ${ }^{17}$ Jef Huysmans has recently put forth this disruptive understanding of acts as a way of reopening debates about the effects of security practice. In his formulation, an act entails 'the creating of a rupturing scene itself, irrespective of its acceptance and institutionalization' (2011: 373). Thus, methods as acts offer a different lens on the production of knowledge and political struggles than methods as devices. Understood in this sense, critical methods do not only rupture knowledge, but also have the capacity to effect political rupture.

In keeping with the focus on ethnographic methods in this section, let us turn to one recent debate on ethnographic method in IR which can shed further light on the second reconceptualisation we propose here. Ethnographic methods have become increasingly popular in IR, with some noting an 'ethnographic turn'. Yet, Wanda Vrasti (2008) has castigated some of this literature for its failure to take account of the debates in critical anthropology. Cynthia Enloe's work is singled out - alongside other feminist, constructivist and poststructuralist work - for being simply an 'ethnofeel' (Vrasti 2008: 288) rather than the supposedly 'authentic' ethnography of critical anthropology. ${ }^{18}$ The main accusation brought to Enloe's work is that women's voices are not 'alive enough' and the 'textual stylisation' is not open to 'a multiplicity of voices, modes of life and political strategies' (Vrasti 2008). However, as Wacquant's criticism makes clear, a debate about ethnographic method cannot focus on the narrative and textual form, but also needs to analyse its political effects.

Irrespective of whether Enloe's work should indeed be understood as ethnographic, ${ }^{19}$ Vrasti's criticism raises a more general issue about the triangulation of method, knowledge and politics. By implying that there is a proper, or more adequate and authentic way of doing ethnography, she locates the significance of the ethnographic method in its form. The credibility of ethnographic knowledge and the solidity of its truth claims would be, in the first instance, a result of the proper application of an ethnographic form of research. However, Enloe's textual method, including its 'ethnofeel,' rests on the substance it brings to bear on knowledge and the

\footnotetext{
${ }^{17}$ Isin's concept of 'act' differs from agency, action, or practice. It refers in particular to practice that is rupturing instituted scripts and thus is not reproductive of given structures, institutions, dispositions. (Isin 2008) In constructionist work on acts and agency the terms are more ambivalently used as both reproductive and transformative (e.g. Giddens 1993). For a more extensive exposition of how the concept of act can be used in this disruptive sense in analyses of European citizenship and mobility, see: Aradau, Huysmans and Squire (2010); Andrijasevic, Aradau, Huysmans and Squire (2012).

${ }^{18}$ In his reply, Rancatore (2010) rightly makes the point that Vrasti opposes an unspecified but 'authentic' ethnography to the 'lesser' ethnography of IR.

${ }^{19}$ Bananas, Beaches and Bases, Maneuvers and the essays collected in The Curious Feminist do not necessarily make use of ethnographic methods and Enloe is clear about the importance of texts in her analysis.
} 
world. Worlds are not enacted through the method form but through the substantive positioning that the method contains. Enloe's work is, not unlike Haraway's call for situated knowledge ${ }^{20}$, driven by a method that takes a position in the world - in her case, the practice of women. She develops 'feminist curiosity' as 'a crucial tool to use today in making sense of the links between two of the world's most potent trends: globalization and militarization' (Enloe 2004: 1-2). 'Feminist curiosity' does not fit a pre-given tool, nor does it express a particular feminist technique. ${ }^{21}$ Rather, feminist curiosity can be seen as an experimental assemblage that Enloe has developed in her work. For Enloe, feminist curiosity simultaneously extracts information from and disrupts worlds where globalisation and militarisation meet. Questioning the conditions of women turns some things that are taken for granted such as the category of 'cheap labour' into issues of struggle.

For us, Enloe's methods cannot be reduced to disciplinary politics of proper theory and method. Enloe uses the language of 'political acts' and 'political action' repeatedly in her works. For instance, in Globalization and Militarism: Feminists make the link, she points out that

Developing a 'curiosity' involves exploring, questioning - refusing to take something for granted. One is not curious about the things one takes for granted. [...] Developing a new kind of curiosity is not just academic. It takes energy. It is political. It is cultural. It is personal. To insist upon posing questions about things that other people take for granted can be a political act (Enloe 2007).

Her methods, we argue, need to be taken seriously as acts which have disruptive political effects. Feminist curiosity is deployed in academic discipline as well as international organisations and companies. When deployed, it disrupts these worlds, for example by enacting feminism in academia or by challenging the gender neutrality of the use of 'cheap labour' in international labour relations. When 'feminist curiosity' is deployed by labour organisations, the enactment of the worlds of cheap labour will be different from when 'cheap labour' is enacted through gender-neutral econometrics or programmes of workers' rights. In doing so, methods already carry a world within them, and not simply forms of doing research. ${ }^{22}$

For Enloe, feminist theory does not subsume method. Method is also not simply derived from feminist theory. Rather, feminist curiosity is an act that experiments with concepts, empirical sites, connects devices in imaginative ways with the purpose of disrupting dominant forms of knowledge and practice. Enloe's methods are inseparable from her claim at the end of Bananas, Beaches and Bases that 'the personal is international'. Read backwards and forwards - the personal is international and the international is personal - this claim is a goal, an orientation about making women visible as much as about understanding why and how the international takes the form it does. Read backwards and forwards, this is also a claim about knowledge and a claim about politics. In this sense, Enloe's work does the opposite that some ethnographic work has done, as pointed out by Wacquant. The

\footnotetext{
20 ‘... only partial perspective promises objective vision.' (Haraway 1988: 583)

${ }^{21}$ Feminist writers have often used a combination or modified versions of feminist methods (DeVault 1996; Harding 1989). However, we relax here the distinction between method and methodology, following DeVault's insight that the method of the feminist movement had been 'consciousness raising' (1996: 30).

${ }^{22}$ For a similar point on social sciences more generally: Herborth (2011).
} 
ordering that methods imply is not a matter of simply interfering in textual establishment and reproduction of 'truth' - i.e. the representation of worlds - but also an attempt at political rupture, both in the academic politics of knowledge production and in confrontations between hierarchically organised worlds that exist simultaneously in practice - e.g. the company as existing in the world of female labour and in the world of the stock market. ${ }^{23}$ What is important about Enloe's methods is not primarily the form of ethnographic research or even that of intertextuality. Like Hansen, Enloe works with a variety of texts. However, the orientation of feminist curiosity experimentally assembles various elements of method, theory, ontology and epistemology in such ways that they produce a political rupture. Feminist curiosity compels Enloe to reject a whole series of ungendered terms through which international politics works: "'military spouses", "child soldiers", "factory managers," "sweatshop workers," "humanitarian aid workers," "rape survivors," "peace activists," "warlords," "occupation authorities"” as showing an absence of curiosity about women and men and their places/placements in international politics (Enloe 2004). Moreover, Enloe argues that if institutions were to practice a method of feminist curiosity, the worlds they currently enact would be disrupted and different worlds would have to be enacted. What matters is the substantive disruption that methods produce and not whether Enloe's methods are ethnographically 'pure' or simply have an 'ethnofeel'.

In developing a conceptualisation of methods as acts, we do not suggest that all methods are or should be thought as rupturing. Our proposal is that all methods are devices that are both in and of the world and that produce truth as well as politics. Yet, as acts, methods can do something quite specific. They disrupt particular scripted, ordered enactments of worlds. The specific politicality of methods as acts does not depend on their form, for example whether being qualitative or quantitative, and neither on an ontological vision that all knowledge is political because it represents partial worlds. Rather, methods as acts are political by bringing forth an orientation informed by subordinate positions that ruptures the ordered and orderly worlds (see alsoAndrijasevic 2013). In other words, the notion of act takes us beyond an ontological politics that follows from the vision that methods circulate in the world and enact the world in this circulation. For the latter, the notion of method-as-device suffices. It includes the idea that methods interfere in worlds, both by making claims about the knowledge of the world and its politics. In this way, methods as devices also carry an idea of politics as making visible alternative worlds. However, such a conceptualisation does not focus on the rupturing quality of methods favouring positional visions of unexpected, subordinated, forgotten, marginalised events, subjects, and things. The latter is central to method-as-act and defines its different politics.

As devices and acts, methods are fragile and fragmented. They are not systematic wholes, like a particular statistical method, a pure ethnography holistically incorporating all the changes and contestation within ethnographic history, a systematised discourse analysis that demands coherence and strict application. Devices can fail and stabilisation is not a straightforward process. Methods as acts often borrow and combine bits and pieces from here and there, and try out new

\footnotetext{
${ }^{23}$ At this point, it is also worth recalling Paul Rabinow's cautionary note, addressed to anthropologists in the $1980 \mathrm{~s}$, that ' $[\mathrm{m}]$ aking textual production the guiding metaphor of the anthropological encounter risks serious distortion' (Rabinow 1985: 6). The politics of method is about something else than form. Rabinow is also wary of the 'equation of avant-garde experiments in form with progressive politics' (Rabinow 1985).
} 
combinations to produce a rupturing effect. As instances shifting instituted worlds they are fragile, in the sense of being often heavily contested by those looking for method as that what provides credibility through its form and consistency as well as in the sense of not always producing the rupture they seek. It is in their fragility, fragmentation, situatedness and experimentation that methods can become acts. They can intervene and disrupt given worlds by creating fragile objectivities from taking position in favour of subjugated knowledge, subjects and objects. Thus understood, methods have more in common with the etymological meaning of method, understood as the pursuit of a goal rather than a set of tools and procedures that are deemed scientific (Toulmin 2003).

\section{Conclusion}

This article has proposed a twofold reconceptualisation of methods as critical methods as devices and acts - to counter-pose the dominance of method as technique in International Relations and social sciences more widely. Taking its cue from debates about method and methodology in IR which have tried to reclaim method for critical approaches, it has argued that methods themselves can be critical if understood as experimentally connecting and assembling ontology, theory, and epistemology.

Method cannot thus be simply derived from theory, ontology and epistemology. In a first step, we have argued that methods are both connecting and inscribing devices. They enact worlds and make particular orderings more visible than others. Drawing on Lene Hansen's work on intertextuality as method, we have shown how actioning intertextuality differently enacts different worlds. Hansen's actioning of intertextuality is different from Kristeva's for instance. In this interpretation, distinctions based on the form of methods - such as qualitative versus quantitative, case study versus survey, autoethnography versus mapping opportunity structures are subordinated to the substantive inscriptions they produce. At the same time, methods and method work are often significantly messier than methodology - i.e. sets of principles against which proper investigation is evaluated - allows for. For Latour and Law for instance, devices are various tools in the laboratory that perform their own operations but also exist within relatively complex networks of other devices, inscriptions, and people which make the inscription activities quite messy

Our second reconceptualisation of method focused on acts rather than devices. If devices enact worlds, we have argued that the concept of act can make sense of the disruptive effects that methods can have. We have drawn on Cynthia Enloe's method of feminist curiosity to illustrate methods as acts. Feminist curiosity allows Enloe to disrupt ordered and orderly understandings of international politics by taking seriously women's life. In our view, understanding methods as acts which disrupt taken-for-granted knowledge and social and political practice allows us to read Enloe's method as substantive intervention rather than proper form or procedure. In that sense, feminist curiosity as method is not about the form of ethnography, intertextuality, interview or discourse analysis. Rather, it is about the substantive effects that the method as act produces. Methods as devices and acts carry, we have argued, particular visions of politics and critique.

The twofold reconceptualisation of methods proposed here departs from how methods have been understood in (critical) international relations on three accounts. Placing methods in relation to claims to knowledge and politics prevents the debate 
on methods to give priority to scientificity and the philosophy of science. Rather than methods as 'meta-theory', we presented method as an enactment of and rupture into the worlds of knowledge and politics. In so doing, our reconceptualisation has shifted from a focus on philosophical assumptions to a focus on political effects. In this double configuration as devices and acts, methods appear messy and fragile, rather than delivering the kind of rigour, scientificity, objectivity, or truth that are the basis for the authority of knowledge in many of the methodological debates. Rather than type-casting methods as delivering a rigorous or objective knowledge contained within a particular epistemology and ontology, the interesting methodological question is what it means and what is at stake in proposing fragile objectivity or messy truth. ${ }^{24}$

Our reconceptualisation of method is not driven by the distinction between quantitative and qualitative methods. For methods as devices and acts, it is not a question of whether statistical analysis, surveys, network analysis or ethnography is used or not. Neither is the 'purity' of a method important. For us, methodological debates are about the substantive worlds enacted through the method and the potential rupture that its enactment creates. This understanding invites eclectic and experimental processes of connecting and assembling. Finally, methods as devices and acts do not endorse the plurality of methods as coexistence through indifference. Starting with methods as devices and acts brings out the political stakes that methods carry and thus the struggles over the worlds that methods enact.

\section{References}

Ackerly, Brooke A., Maria Stern, and Jacqui True. 2006. Feminist Methodologies for International Relations. In Feminist Methodologies for International Relations, ed. Brooke A. Ackerly, Maria Stern and Jacqui True:3-18. Cambridge: Cambridge University Press.

Agnew, John. 1998. Geopolitics. Re-Visioning World Politics London: Routledge.

Albro, Robert. 2010. Anthropology and the Military: Africom, 'Culture' and Future of Human Terrain Analysis (Respond to This Article at Http://Www.Therai.Org.Uk/at/Debate). Anthropology Today 26, no. 1: 22-24.

Alker, Hayward. 1996. Rediscoveries and Reformulations: Humanistic Methodologies for International Studies. Cambridge: Cambridge University Press.

Amoore, Louise. 2009. Algorithmic War: Everyday Geographies of the War on Terror. Antipode 41, no. 1: 49-69.

Andrijasevic, R., C. Aradau, J. Huysmans, and V. Squire. 2012. European Citizenship Unbound: Sex Work, Mobility, Mobilisation. Environment and Planning D: Society and Space 30, no. 3: 497-514.

Andrijasevic, Rutvica. 2013. Acts of Citizenship as Methodology. In Enacting European Citizenship, ed. Engin Isin and Michael Saward. Cambridge: Cambridge University Press.

\footnotetext{
${ }^{24}$ The question is not how to apply a method so it produces objectivity. Rather, this position asks for locating methods in the history of the formation of objectivity (the historical fragility of objectivity) (Daston and Galison 2007) and connecting methods to conceptions of objectivity that demand taking position and immersion in worlds (messy objectivity) (Harraway 1988) rather than the careful policing of distance between researcher and worlds.
} 
Aradau, Claudia. 2010. Security That Matters: Critical Infrastructure and Objects of Protection. Security Dialogue 41, no. 5: 491-514.

Aradau, Claudia, Jef Huysmans, and Vicki Squire. 2010. Acts of European Citizenship: A Political Sociology of Mobility. JCMS: Journal of Common Market Studies 48, no. 4: 945-965.

Aradau, Claudia and Rens Van Munster. 2011. Politics of Catastrophe: Genealogies of the Unknown. Abingdon: Routledge.

Bleiker, Roland. 2001. The Aesthetic Turn in International Political Theory. Millennium: Journal of International Studies 30, no. 3: 509-533.

Bleiker, Roland and Morgan Brigg. 2010. Introduction to the Ris Forum on Autoethnography and International Relations. Review of International Studies 36, no. 03: 777-778.

Booth, Ken. 2007. Theory of World Security. Cambridge: Cambridge University Press.

Checkel, Jeffrey. 1998. The Constructivist Turn in International Relations Theory. World Politics 50, no. 2: 324-348.

Clough, Patricia Ticineto. 2010. The Case of Sociology: Governmentality and Methodology. Critical Inquiry 36, no. 4: 627-641.

Connolly, William E. 2004. Method, Problem, Faith. In Problems and Methods in the Study of Politics, ed. Ian Shapiro, Rogers M. Smith and Tarek E. Masoud:332349. Cambridge: Cambridge University Press.

Daston, Lorraine and Peter Galison. 2007. Objectivity. Cambrige, MA: MIT Press.

DeVault, Marjorie L. 1996. Talking Back to Sociology: Distinctive Contributions of Feminist Methodology. Annual Review of Sociology 22, no. ArticleType: research-article / Full publication date: 1996 / Copyright (C) 1996 Annual Reviews: 29-50.

Enloe, Cynthia. 2004. The Curious Feminist. Searching for Women in a New Age of Empire. Berkeley, CA: University of California Press. . 2007. Globalization and Militarism: Feminists Make the Link. London: Rowman \& Littlefield.

Enloe, Cynthia 1989. Bananas, Beaches \& Bases. Making Feminist Sense of International Politics. London: Pandora Press.

ESRC. Research Methods Programme. http://www.esrc.ac.uk/ images/RMP tcm82728.pdf (accessed 4 April, 2011).

Fluehr-Lobban, Carolyn. 2008. Anthropology and Ethics in America's Declining Imperial Age. Anthropology Today 24, no. 4: 18-22.

Friedrichs, Jörg and Friedrich Kratochwil. 2009. On Acting and Knowing: How Pragmatism Can Advance International Relations Research and Methodology. International Organization 63, no. 04: 701-731.

Frost, Mervyn. 1998. A Turn Not Taken: Ethics in Ir at the Millenium. Review of International Studies 24, no. 05: 119-132.

Giddens, Anthony. 1993. New Rules of Sociological Method: A Positive Critique of Interpretative Sociologies. Stanford, CA: Stanford University Press.

Gonzalez, Roberto J. 2007. Towards Mercenary Anthropology? The New Us Army Counterinsurgency Manual Fm 3-24 and the Military-Anthropology Complex. Anthropology Today 23, no. 3: 14-19.

Gusterson, Hugh. 2007. Anthropology and Militarism. Annual Review of Anthropology 36, no. 1: 155-175. 
. 2008. Ethnographic Research. In Qualitative Methods in International Relations: A Pluralist Guide, ed. Audie Klotz and Deepa Prakash. New York: Palgrave Macmillan.

Hacking, I. 2004. Historical Ontology. Cambridge, Mass.: Harvard University Press.

Hacking, Ian. 2007. Kinds of People: Moving Targets. In Proceedings of the British Academy, 151:285: Oxford University Press.

Hafner-Burton, Emilie M., Miles Kahler, and Alexander H. Montgomery. 2009. Network Analysis for International Relations. International Organization 63, no. 03: 559-592.

Hansen, Lene. 2006. Security as Practice. Discourse Analysis and the Bosnian War. London: Routledge.

Haraway, Donna. 1988. Situated Knowledges: The Science Question in Feminism and the Privilege of Partial Perspective. Feminist Studies 14, no. 3: 575-599.

Harding, Sandra. 1987. The Method Question. Hypatia 2, no. 3: 19-35.

. 1989. Is There a Feminist Method. In Feminism \& Science, ed. Nancy Tuana:17-31. Bloomington, IN: Indiana University Press.

Hawkesworth, Mary. 2006. Contending Conceptions of Science and Politics: Methodology and the Constitution of the Political. In Interpretation and Method. Empirical Research Methods and the Interpretive Turn, ed. Dvora Yanow and Peregrine Schwartz-Shea:27-49. New York: M. E. Sharpe.

Herborth, Benjamin. 2011. Methodenstreit - Methodenzwang - Methodenfetish. Zeitschrift für Internationale Beziehungen 18, no. 2: 137-151.

Huysmans, Jef. 2006. The Politics of Insecurity: Fear, Migration and Asylum in the $E u$. Abingdon: Routledge.

2011. What's in an Act? On Security Speech Acts and Little Security Nothings. Security Dialogue 42, no. 4-5: 371-383.

Isin, Engin F. 2008. Theorizing Acts of Citizenship. In Acts of Citizenship ed. Engin F. Isin and Greg M. Nielsen:15-43. London: Zed Books.

Jackson, Patrick T. 2011. The Conduct of Inquiry in International Relations. London: Routledge.

Klotz, Audie and Cecelia Lynch. 2007. Strategies for Research in Constructivist International Relations: M. E. Sharpe.

Kristeva, Julia. 1980. Desire in Language: A Semiotic Approach to Literature and Art. Trans T. Gora, A. Jardine and L. Roudiez. New York: Columbia University Press.

. 1986. Revolution in Poetic Language. In The Kristeva Reader, ed. Toril Moi:89-136. Oxford: Basil Blackwell.

Latour, Bruno. 1990. Drawing Things Together. In The Map Reader: Theories of Mapping Practice and Cartographic Representation ed. Martin Dodge, Rob Kitchin and Chris Perkins:65-72. Chichester, UK: Martin Wiley \& Sons.

. 1999. Pandora's Hope: An Essay on the Reality of Science Studies. Cambridge, Mass.: Harvard University Press.

Law, John. 2004. After Method: Mess in Social Science Research. Abingdon: Oxford. 2009. Seeing Like a Survey. Cultural Sociology 3, no. 2: 239-256.

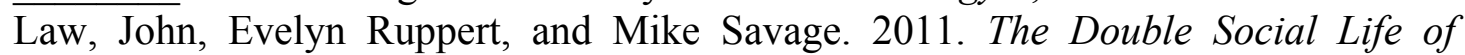
Methods. Milton Keynes: Open University.

Law, John and John Urry. 2004. Enacting the Social. Economy and society 33, no. 3: 390-410. 
Lundborg, Tom and Nick Vaughan-Williams. 2011. Resilience, Critical Infrastructure, and Molecular Security: The Excess of "Life" in Biopolitics. International Political Sociology 5, no. 4: 367-383.

Lury, Celia and Nina Wakeford. 2012. Introduction: A Perpetual Inventory. In Inventive Methods: The Happening of the Social, ed. Celia Lury and Nina Wakeford. Abingdon: Routledge.

Milliken, Jennifer. 1999. The Study of Discourse in International Relations: A Critique of Research and Methods. European Journal of International Relations 5, no. 2: 225-254.

Neumann, Iver B. 2002. Returning Practice to the Linguistic Turn: The Case of Diplomacy. Millennium - Journal of International Studies 31, no. 3: 627-651.

Norton, Anne. 2004. Political Science as a Vocation. In Problems and Methods in the Study of Politics, ed. Ian Shapiro, Rogers M. Smith and Tarek E. Masoud:6782. Cambridge: Cambridge University Press.

Pouliot, Vincent. 2007. "Sobjectivism": Toward a Constructivist Methodology. International Studies Quarterly 51, no. 2: 359-384.

Rabinow, Paul. 1985. Discourse and Power: On the Limits of Ethnographic Texts. Dialectical Anthropology 10, no. 1: 1-13. . 2003. Anthropos Today. Reflections on Modern Equipment. Princeton: Princeton University Press.

Rancatore, Jason P. 2010. It Is Strange: A Reply to Vrasti. Millennium-Journal of International Studies 39, no. 1: 65.

Ressler, Steve. 2006. Social Network Analysis as an Approach to Combat Terrorism: Past, Present, and Future Research. Homeland Security Affairs 2, no. 2: 1-10.

Robson, Karen and Chris Sanders, eds. 2009. Quantifying Theory: Pierre Bourdieu. London: Springer.

Ruppert, Evelyn. 2011. Population Objects: Interpassive Subjects. Sociology 45, no. 2: 218-233.

Savage, Mike. 2010. Identities and Social Change in Britain since 1940s: The Politics of Method. Oxford: Oxford University Press.

Sluka, Jeffrey A. 2010. Curiouser and Curiouser: Montgomery Mcfate's Strange Interpretation of the Relationship between Anthropology and Counterinsurgency. PoLAR: Political and Legal Anthropology Review 33: 99115.

Smith, L. T. 2006. Decolonizing Methodologies: Research and Indigenous Peoples. London: Zed Books.

Sprinz, D.F. and Y. Wolinsky-Nahmias. 2004. Models, Numbers, and Cases: Methods for Studying International Relations: Univ of Michigan Pr.

Sylvester, Christine. 1994a. Empathetic Cooperation: A Feminist Method for Ir. Millennium - Journal of International Studies 23, no. 2: 315-334.

Sylvester, Christine 1994b. Feminist Theory and International Relations in a Postmodern Era Cambridge: Cambridge University Press.

Tickner, Ann J. 2006. Feminism Meets International Relations: Some Methodological Issues. In Feminist Methodologies, ed. B. A. Ackerly and Maria Stern:19-41. Cambridge: Cambridge University Press.

Tickner, J. Ann. 1997. You Just Don't Understand: Troubled Engagements between Feminists and Ir Theorists. International Studies Quarterly 41, no. 4: 611.

Toulmin, Stephen. 2003. Return to Reason. Cambridge, MA: Harvard University Press. 
Vrasti, Wanda. 2008. The Strange Case of Ethnography and International Relations. Millennium - Journal of International Studies 37, no. 2: 279-301.

Wacquant, Loïc. 2002. Scrutinizing the Street: Poverty, Morality, and the Pitfalls of Urban Ethnography. American Journal of Sociology 107, no. 6: 1468-1532.

Waever, Ole. 1996. The Rise and Fall of the Inter-Paradigm Debate. In International Theory: Positivism and Beyond, ed. Steve Smith, Ken Booth and Marysia Zalewski:156-157. Cambridge: Cambridge University Press.

Walker, R. B. J. 1993. Inside/Outside: International Relations as Political Theory. Cambridge: Cambridge University Press.

Wedeen, Lisa. 2010. Reflections on Ethnographic Work in Political Science. Annual Review of Political Science 13, no. 1: 255-272.

Wendt, Alexander. 1999. Social Theory of World Politics. Cambridge: Cambridge University Press.

Wight, Colin. 2006. Agents, Structures and International Relations: Politics as Ontology. Cambridge: Cambridge University Press.

Yanow, Dvora. 2006a. Neither Rigorous nor Objective? Interrogating Criteria for Knowledge Claims in Interpretive Science. In Interpretation and Method. Empirical Research Methods and the Interpretive Turn, ed. Dvora Yanow and Peregrine Schwartz-Shea:67-88. New York: M. E. Sharpe.

. 2006b. Thinking Interpretively: Philosophical Presuppositions and the Human Sciences. In Interpretation and Method. Empirical Research Methods and the Interpretive Turn, ed. Dvora Yanow and Peregrine Schwartz-Shea:526. New York: M. E. Sharpe.

Yanow, Dvora and Peregrine Schwartz-Shea, eds. 2006. Interpretation and Method: Empirical Research Methods and the Interpretive Turn. New York: M. E. Sharpe.

Yusoff, K. 2009. Excess, Catastrophe, and Climate Change. Environment and Planning D: Society and Space 27, no. 6: 1010-1029. 